\title{
Intermediary levels of government for the development of productive agglomerations: viable implementations for emerging countries
}

\section{Nelson Casarotto Filho}

Department of Production Engineering, Federal University of Santa Catarina, Campus Universitário, Caixa Postal 476, Trindade, Florianópolis, SC 88040-900, Brazil

Email: nelson.casarotto@ufsc.br

\section{Marcos Ferasso*}

Department of Strategy, KEDGE Business School,

Marseilles Campus, R. Antoine Bourdelle, Domaine de Luminy, Marseilles, PACA 13009, France

Email: admmarcosferasso@gmail.com

*Corresponding author

\section{Jorge Alberto Velloso Saldanha}

Human and Social Sciences Institute,

Federal Rural University of Rio de Janeiro,

Av. Prefeito Alberto da Silva Lavinas, de 705/706,

Centro, Três Rios, RJ 25802100, Brazil

Email:javsa@terra.com.br

\begin{abstract}
Although the cluster concepts are well-stressed in literature, and in several industries intensities, there are still some contributions that can be addressed to emerging countries. This article has as main objective to discuss the regional space for the development focusing the productive agglomerations and proposes a model of multilevel governance to assist the process of regional development which is important to generate income and increase the quality of life of the inhabitants of a given region. The space for regional development stems from the confrontation of two vectors: the first is the scale for development projects and the second is that of cooperation. A framework is built based on literature and a possible implementation in a Brazilian cluster is analysed.
\end{abstract}

Keywords: productive agglomerations; governance; economic development; political policies; regions.

Reference to this paper should be made as follows: Casarotto Filho, N., Ferasso, M. and Saldanha, J.A.V. (2019) 'Intermediary levels of government for the development of productive agglomerations: viable implementations for emerging countries', Int. J. Strategic Business Alliances, Vol. 6, No. 4, pp.251-266. 
Biographical notes: Nelson Casarotto Filho is an Associate Professor from the Federal University of Santa Catarina. He earned his undergraduate in Chemical Engineering from the Universidade Federal do Rio Grande do Sul, in 1974, Master's in Production Engineering from the Universidade Federal de Santa Catarina, in 1977 and $\mathrm{PhD}$ in Production Engineering from the Universidade Federal de Santa Catarina, in 1995. He has experience in production engineering, focusing on evaluation of projects, acting on the following subjects: regional development, companies' networks, industrial competitiveness, investments analyses, and competitiveness.

Marcos Ferasso earned his Bachelor in Management in 2002 and his specialisation in Business Management from UNOESC (Brazil) in 2005, and his specialisation in Local Development from ILO/UN (Italy) in 2006. He earned his MSc in Management from UFRGS (Brazil) in 2009, with exchange period at Euromed-Marseille Ecole de Management (France). He earned his $\mathrm{PhD}$ in Management from UFPR (Brazil) with exchange period at Forsyth Technical Community College (USA). He holds a post-doctorate from IMED Faculty (Brazil) with exchange period at KEDGE Business School (France). He is currently a Visiting Researcher and Professor at KEDGE Business School.

Jorge Alberto Velloso Saldanha is an Associate Professor from the Federal Rural University of Rio de Janeiro. He earned his undergraduate Diploma in Administration from the Universidade Federal de Santa Catarina, in 1999, Master's in Administration from the Universidade Federal de Santa Catarina, in 2004, and $\mathrm{PhD}$ in Production Engineering from the Universidade Federal de Santa Catarina, in 2009. He has experience in production engineering, acting on the following subjects: marketing, local development, satisfaction, collective transportation and satisfaction.

This paper is a revised and expanded version of a paper entitled 'Níveis intermediários de governo e sua relação com a intervenção para o desenvolvimento de aglomerações produtivas', presented at III Encontro de Estudos em Estratégia (3Es) ANPAD, São Paulo, Brazil, 9-11 May 2007.

\section{Introduction}

The industrial cluster literature already addressed several researches by proposing most valuable concepts and models to help practitioners and academia to enhance clusters actors to achieve competitiveness and innovations. Despite the well-developed countries that already addressed this theme, such as Italy and France, there are still some trends that can be suitable in the context of emerging countries. This is the main contribution of this paper, by which we intend to discuss the regional space for the development focusing the productive agglomerations and proposes a model of multilevel governance to assist the process of regional development.

The space for regional development stems from the confrontation of two vectors: the first is the scale for development projects. There must be a minimum of scale, which is dependent on population and income, and the second factor is cooperation. There should be a maximum size that is dependent on economic vocation, culture, history, language. Brazil is currently trying to implement development projects in several states, such as the Coredes - Regional Development Councils in Rio Grande do Sul, or the SDRs Secretaries of Regional Development (now transformed in ARDs - Agencies of Regional 
Development), in Santa Catarina, or the Cooperation Agreements in Ceará. Analysing those cases, we perceived that none reached the point of creating an intermediate level of government as occurred, for example, in the Italian or French provinces. Thus, the effective intervention for the development of productive agglomerations passes by the consideration of the 'meso level' of governance.

A space for the birth of a productive agglomeration is when formal space of microregion government becomes a combination of public-private efforts to promote the microregion. This will lead on added value to all the products that are manufactured in this given region. This article intends to underline the characterisation of the integration instruments of a local productive system, focusing on mechanisms for integration based on the Italian agglomeration production model as a possibility to strengthen governance in emerging economies. The main consideration is that, by promoting the 'meso level' governance, it will be possible to trigger sharing among regional actors which, in turn, result on the development and competitiveness of a given cluster.

The approach of local production systems is stressed theoretically to further, present the integration instruments that facilitate the acceleration of intervention process for development. To analyse empirically these assumptions, a Brazilian cluster on textile industry from Santa Catarina was selected.

This paper is structured, beyond this introduction section, by a section devoted to discussing the local productive systems followed by the presentation of the space for development section. The mechanisms of regional integration are presented and discussed in the fourth section, where a model is proposed. The paper ends on a conclusions section followed by consulted references.

\section{Local productive systems}

A local productive system is a macro associative network built on mechanisms of integration of all representative regional actors aiming the development of such region. The local productive system is a highly structured region characterised by one or more clusters. This region is based on planning and on constant public-private interactions aiming the 'quality of life' of inhabitants.

A cluster is a geographically concentrated group of inter-related companies and related institutions in a particular area, linked by common elements and complementarities (Porter, 1999), and clusters are widely known as competitive agglomerations. The cluster develops on the regional vocation and may contain companies manufacturing products that try to organise the added value downstream (services) or upstream (suppliers) and include associations of private support or relationships with the government. Although a cluster may present a complex form, it does not necessarily contain a whole production chain.

A cluster can contain several consortia or correspond to a single large regional consortium. For example, a furniture cluster may contain a consortium of office furniture and a consortium of house furniture, and a consortium of equipment manufacturers for furniture manufactures. It may also contain other companies that not participate of the consortiums.

Within a cluster, the relationships among their inner actors may be characterised as informal ties. Table 1 shows the stages of cluster's life cycle since the first formal 
relationships among some companies and grown up to a stage characterised by structured and formalised relationships among actors (consortia and networks with a main cluster's company) and some strong integration with support institutions.

Table 1 Cluster's life cycle

\begin{tabular}{llll}
\hline Pre-cluster & \multicolumn{1}{c}{ Cluster's birth } & \multicolumn{1}{c}{$\begin{array}{c}\text { Cluster under } \\
\text { development }\end{array}$} & \multicolumn{1}{c}{ Structured cluster } \\
\hline $\begin{array}{l}\text { Few companies } \\
\text { focused to a } \\
\text { single product in }\end{array}$ & $\begin{array}{l}\text { Major concentration } \\
\text { of companies and } \\
\text { isolation. }\end{array}$ & $\begin{array}{l}\text { Relationships } \\
\text { increased, consortia } \\
\text { relationships. }\end{array}$ & $\begin{array}{l}\text { Formalised consortium, local } \\
\text { ftructured system formed, } \\
\text { strong public-private } \\
\text { partnerships established. }\end{array}$ \\
\hline
\end{tabular}

Note: Companies institutions.

Source: Casarotto Filho and Pires (2000, p.70)

Figure 1 Representation of macro network of a local productive system

STRUCTURED PRODUCTIVE SYSTEM

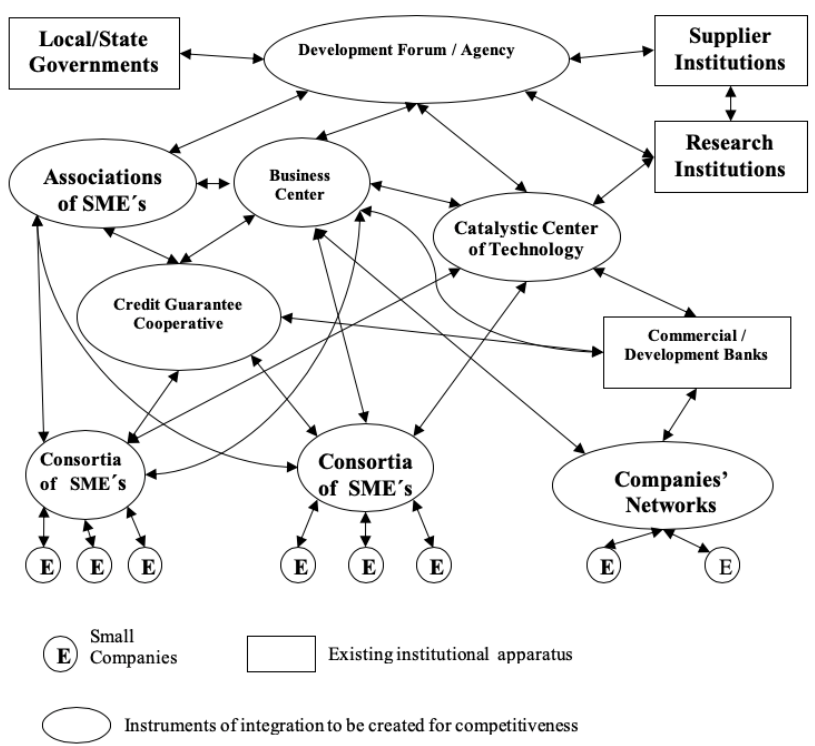

Source: Casarotto Filho and Pires (2000, p.22)

In literature, the seminal clusters concept came from Marshall (1890), who described the economies of agglomeration in England and collective efficiency. Further, Becattini (1979) described the phenomenon of the Italian Industrial Districts, or active agglomeration economies, in which there was a process of regional intervention of public/private character (government and companies) for the development of an industrial district, especially for the valorisation of products and regional development. Whereas 
the Marshalian districts ideas were based on a laissez-faire regional growth, the Italian districts growth conceptions consider the government intervention.

The vision of the Italian districts where there are public-private interventions for cluster development and region development is what standout on development system local productive approach. The difference resides on the objectives for analysis, planning and intervention of regions. Whereas the analysis approach aims to boost cluster competitiveness, the approach of local development aims the quality of life for all inhabitants in the region (Saublens et al., 1999). The created macro network and the integration mechanisms are the results of a broader regional planning than a simple analysis of a value chain or an analysis of the cluster in isolation. A local productive system and the interactions among public-private actors, as occurs in Northern Italy are summarised in Figure 1.

It is observed that there are several mechanisms and actors for the regional integration, which occurs usually on a virtual character, and this system is characterised by an above structure, i.e., a ARDs for territorial governance. Currently, an ADR is considered as an instrument for integration of fourth degree level, once this agency represents the whole region and their inner members are public and private organisations that aiming the region development.

\section{The space for development}

What comprises a region and what is the appropriate size of a region for development promotion? As stated previously, the space for regional development stems from the confrontation of two vectors: the first is the scale development projects where there must be a scale minimum, which is dependent on population and income. The second vector is cooperation where there should be a maximum size, which will dependent on economic vocations and social characteristics (e.g., culture, history, and language).

There are emerging countries that are targeting a more planned regional development. In Brazil, it is perceived some attempts, but none are concerned on creating an intermediary level of government as seen in Italian provinces (Silveira, 1999). The Italian case evidenced that the effective intervention for the development of productive agglomerations undoubtedly pass by that consideration. When there is a space for the emergence of a productive agglomeration, and a formal space for the emergence of government structures at micro-level, it is easier to combine public-private efforts targeting to promote the region what will impact on the value of regional products.

According to Bianchi (1995), the European policy for regional development is presented in Table 2, where are shown 12 territorial divisions in the Europe reaching the NUTS 3 level (European Union, 2003), which is equivalent to an Italian province.

Gomes (1997) explained that in Europe there are 1,044 territorial spaces of third level classification, which in Brazil corresponds to a micro region. This division is used by statistics purposes of the Brazilian Institute for Statistics and Geography (IBGE), but several attempts to create a 'meso-government' level or some kind of governance were taken, such as the Regional Development Secretary (in Santa Catarina), Regional Development Councils (in Rio Grande do Sul), and the Cooperation Agreements (in Ceará). However, none of those attempts are considering the Italian province approach. 
Noteworthy, governance is the established government and governability is a set of conditions that facilitate the government actions (such as councils, development forums, development agencies, among others).

Table 2 Twelve territorial divisions in Europe

\begin{tabular}{|c|c|c|c|}
\hline \multicolumn{4}{|c|}{$\begin{array}{l}\text { European Union (EUR 12) regional and sub-regional division } \\
\text { Matches between regions of the union and the member countries }\end{array}$} \\
\hline Country & $\begin{array}{l}\text { NUTS } 1 \text { area } \\
\text { (quantity) }\end{array}$ & NUTS 2 area - (quantity) & $\begin{array}{l}\text { NUTS } 3 \text { area }- \\
\text { (quantity) }\end{array}$ \\
\hline Belgium & Régions (3) & Provinces (9) & Arrondissements (43) \\
\hline Denmark & (1) & (1) & Amster (15) \\
\hline Greece & $\begin{array}{l}\text { Development group } \\
\text { areas (4) }\end{array}$ & Development areas (13) & Nomoi (51) \\
\hline Spain & $\begin{array}{l}\text { Group of autonomous } \\
\text { communities (7) }\end{array}$ & $\begin{array}{l}\text { Autonomous communities } \\
+ \text { Melilla and Ceuta }-(17)\end{array}$ & Provinces $(50)$ \\
\hline Germany & Läñder (16) & Regierungsbezirke (40) & Kreise (545) \\
\hline France & ZEAT + DOM3 (9) & Régions (26) & Départaments (100) \\
\hline Ireland & (1) & (1) & Planning regions (9) \\
\hline Italy & (1) & Regioni (20) & Provincie (95) \\
\hline $\begin{array}{l}\text { Luxembourg } \\
\text { (no division) }\end{array}$ & (1) & (1) & (1) \\
\hline Netherlands & Landsdelen (4) & Provincies (12) & COROP-Regio's (40) \\
\hline Portugal & $\begin{array}{c}\text { Continent }+ \\
\text { autonomous areas (3) }\end{array}$ & $\begin{array}{l}\text { Com. coord. areas (1) } \\
\text { Autonomous areas (7) }\end{array}$ & Councils groups (30) \\
\hline UK & Standard regions (11) & Groups of counties (35) & $\begin{array}{c}\text { Counties/local } \\
\text { authority areas (65) }\end{array}$ \\
\hline Totals EUR 12 & 61 & 183 & 1,044 \\
\hline
\end{tabular}

Notes: ZEAT $=$ Zones économiques d'aménagement du territoire; DOM = Département d'outre mer.

Source: Based on European Union (2003)

In Italy, a province has an average of 500,000 inhabitants and, usually, there is a very close space between the province territory and Italian clusters. For example, the Ceramic District of Emilia Romagna has $80 \%$ of their companies located in the province of Modena. This particularity facilitates the public-private partnerships for district's development for territorial valorisation, integration of several industries within the value chain of ceramics industry (tiles, tile floors, equipment, colorants, design, fairs, tourism, among others) (Gomes, 1997).

Biancu (2003) described the role of the provinces as a round table of coordination that joins all participants to manage a defined territory; the round table only is the engine and operational tool that brings together different actors, namely, syndicates, business associations, public and private corporations, and the Province which has a specific and central role. As definition, the provinces would be considered as intermediary administrations between the region and the municipalities, territorial divisions composed of municipalities that are chosen to form, from language and traditions point of view, more homogeneity and more reciprocal integration. 
According to Biancu (2003), the role of the provinces is to select and verify the documentation of submitted projects and deliver them to a technical-economic committee, which intends to attend all specific requirements. This technical-economic committee evaluates the overall coherence of all submitted interventions, each initiative towards entrepreneurship, each public intervention related to infrastructure and functional objectives. The negotiated schedule of projects implementation is the key instrument for development.

Biancu (2003) reported that the main component of all approved projects is a general agreement among the social parties, public regulation entities and companies. The provinces have worked with important themes related to economic growth for several tools, in particular, the development of production chains, the renewal of degraded industrial areas and the support for the growth of innovative small and medium-sized enterprises (SMEs).

The basic elements of this model, i.e., the Italian model of provinces, for regional development can be summarised as (Biancu, 2003):

a The territorial focus: The territory delimitation is not previously defined but is defined by social actors who have to articulate the idea (region project), they need to define a particular area in relation to specific development goals and which can be expanded or reduced considering all involved actors.

b Bottom-up model (endogenous development): This model is key for local development, but it is more difficult to implement due it is based on the concept of cooperative participation.

c Participation: The most important aspect is the understanding of who are the actors, how and who should participate, the main purpose is to seek a collective synthesis that surpass local interests and individual preferences to promote the creation and dissemination of a cooperation climate that institutionalises collective participation.

d Partnership: The social parties are key elements of definition and implementation process of a local development program, linked to the principles of co-financing and co-management (which was introduced by the reform of European Structural Funds - ESF), where every participating actor must contribute a portion of their own resources.

e Municipalities roles: It is a main role in animating, coordinating, planning, and implementation. The municipality should be an active actor for encouragement and mobilisation of socio-economic local resources, it needs to be a partner of companies, cooperatives and associations that operate in the territory. The municipality must be a true agent of development and active local operator, as seen in the leader programs.

On the next section, it is examined the main instruments of regional integration (governability instruments), especially the aspect of development of productive agglomerations. It is underlined that what is considered refers particularly to the Italian case, where there are provinces and government in these provinces. In Brazilian case, these instruments would be equal to state governments or governance mechanisms (e.g., regional secretariats or associations of municipalities), which are weaker if compared with the Italian provinces. 


\section{The cluster's mechanisms of regional integration: the development agencies}

A regional specialisation represents an economic concentration in the production chain and involves social risks for each region. It is at this point that the operating mechanisms of integration must act. The cluster must be supplied by the prospective information and should be addressed to cutting-edge technologies to reach global competitiveness.

The support for development of a $R \& D$ platform, information, services and training can be more effective if catalysed by an institution capable of organising development training programs within their facilities. An institution of the type inter-institutional platform, like the modern European sectoral development agencies, serves as a broker for the development of companies in the region.

The sectoral agencies promote, implement and manage selected projects in a specific production chain/industry. Some ADRs may also have a functional character. The functional ADRs promote, implement and manage projects in a specific function for the region, such as culture, technology, education and credit.

An example of an Italian sectorial agency is Textile Information Center of Emilia Romagna (CITER), located in the commune of Carpi, province of Modena. It provides information services on fashion, market and technology for companies in the agglomerate, in addition to coordinating various programs of technological development, training, certification. It also provides services to other textile/clothing agglomerations in the Emilia Romagna region. Their partners are the public government, companies' associations, banks, and about four hundred companies in the region (Fumagalli and Trenti, 2012; Mosconi, 2012).

A functional/sectorial agency is the Centuria Technological Science Park, in Cesena, also in Emilia Romagna, an agro-industrial region. It provides services similar to those of CITER, but with a greater emphasis on technological development: refrigeration technologies, packaging, processes, among others. This agency also conducts market research and training programs. Both Centuria and CITER agencies have the characteristic of virtuality, they have few employees, and more articulated projects and services than they actually perform (Fumagalli and Trenti, 2012; Mosconi, 2012).

The most common, but also more complex, objective of the development agencies is the economic development of the cluster. This task involves, in one hand, to consider the goals for planning the area and, secondly, assistance to companies. The success of these actions is increasingly influenced by the ability of the agencies to:

1 Changing the behaviour and culture of the region and restructure them around a well-defined program, accepted by all public and private actors, taking advantage of the strength of the regions where they operate and trying to eliminate their weaknesses.

2 Operate in the market niches that are not being covered by private sector (consulting companies) in the field of services to companies.

3 Finding the balance between measures for development of the region and its real endogenous potential.

4 To consider that a development agency is a privileged local actor for the definition and implementation of a strategy for regional development. Therefore, the agency must participate in: 
- definition of this strategy

- mobilisation of all actors on the strategy, including politicians

- mobilisation of funds in 'leverage' effect

- identification of pilot projects

- promotion of granting financial assistance (since the micro-projects offer a faster return on investments and could have a demonstrative effect to be considered, causing the population get confidence in their capabilities)

- in the supply of small and nearby infrastructure

- the attraction of investments from private sector

- maintaining a quality level.

The two main tasks of the agency will be the achievement of a political consensus on the strategy and to ensure the availability of public and private funds for the implementation of that strategy.

In summary, the purpose of an agency for development should be guided by three major functions:

- consultation and harmony with local/regional actors

- complementarity and development of synergies among actions and duties of such actors

- partnership between the actors.

Figures 2 and 3, due their differences, show the functions of a sectoral ADR. Figure 2 shows a typical scheme of a cluster in Brazil, not structured, in which public and private institutions in the region seeking to provide support for economic activities, but without articulation. Sometimes there is a university, a technical school, or an entity as the National Service for Industrial Learning (SENAI) offering trainings, research, technical services, often overlapping. The efficiency is low, and waste is high in this agglomeration form.

Figure 3 shows how the cluster might be structured. It is noticed the sectoral ADR acts as an inter-institutional platform that articulates competencies. Each institution can provide support services on information, training, technology and other kind of support. It is necessary an articulator that organise effective programs where these competencies are utilised in the best way. The articulator must be legitimate due their own local institutions are the members of the ADR. It is noteworthy that companies are structured in consortia of SMEs or supply chains for larger companies, which facilitates the performance of the ADR.

Supporting the formation of companies' consortia or supply chains is a first example of a successful activity of an ADR.

In Brazil, it is common to see a series of studies on clusters, with many diagnoses, other with diagnoses and action plans, but are notorious the problems when starting the process of intervention to implement them. Who leads the process? That means to ask, 'Who has legitimacy to initiate the process, command him maintaining the continuity?'

The forms of structuring an ADR and the goals have changed over time, depending on the environment and the forms of competition. For example, in Emilia Romagna, it was created the system ERVET - Development Agency of Emilia Romagna 
(Casarotto Filho et al., 1996). The ERVET was created in 1974 and addressed to create or participate in the creation of mechanisms of integration in each province where there was a cluster (called Distretto Industriale). For example, from 1976 to 1980 it was structured the CITER in the clothing cluster (Lorenzoni, 1992; Cossentino et al., 1997).

Figure 2 A not-structured cluster

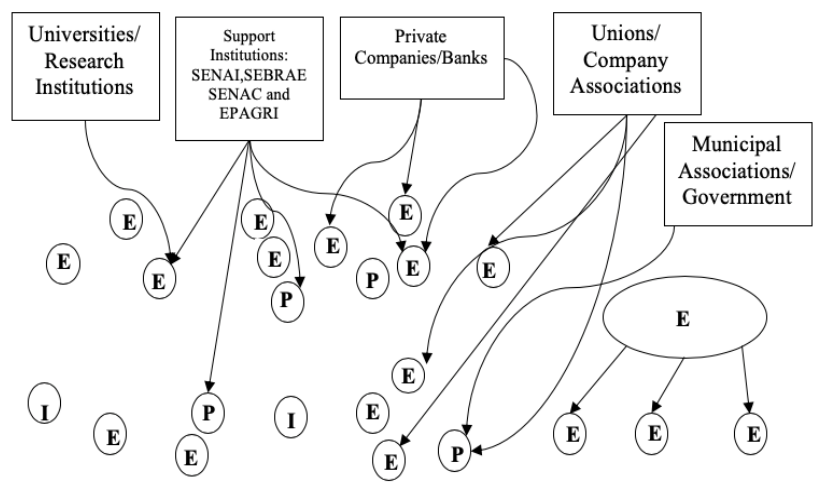

Source: The authors

Also, in Modena, it was setup a centre for the ceramic coating, a centre for mechanic-agricultural in Parma, in Cesena a participation in the agricultural/industrial park of Centuria. In the second half of the 1990 s, each of these clusters was considered a world leader in high value aggregation. In ceramics, the value is in the design and equipment, in clothing the value is in the brands and the design, in the agricultural industry the value is on the conservation technology and quality of products, including packaging.

The main peculiarity of these integration centres is that their members were the leaders of the local production chain and the public actors (Esser et al., 1994). They are considered macro-consortia exercising leadership on the cluster's actors and have legitimacy to develop programs, matching the service's demand and offer actors. Normally they not do this, but they articulate the competencies of those who form, and which are their own members. These Italian service centres operate like ADRs by deploying to support industrial districts.

On the other hand, the transfer of links from the value chain of industrial districts to Eastern European and Asian countries is changing their structure (Coltorti et al., 2016). The microregions are losing part of value aggregation and consequently job positions, once this can be replaced by the greater value aggregation at the end of districts value chain. Many of the service centres in Italy have ceased to exist or their functions had change.

Nowadays, the region of Emilia Romagna is reorienting their intervention for innovation (Bertini, 2012). At this stage, one of the agencies, ASTER, which worked functionally with technology, had their existence questioned in the 2000s, and now returns as a consortium that manages a network of innovation and knowledge. A regional partnership was established for research and innovation among the region, university and 
research entities, and companies, and the high-tech regional network was created among research laboratories and innovation centres.

The idea of such representation in the form of lens was created by Chamala (1999). He used the form of lens to represent the inter-institutional platform that organises the regional competencies. On the top, there are various regional government actors and at the bottom, the mechanism of inter-institutional integration.

For example, to specify how the integration instrument can works, it will be analysed the textile/clothing cluster in Itajaí's Valley, Santa Catarina. Currently, in the region, there is a large textile/clothing cluster with more than 4,000 companies, among fabric, fabric factories, shops, components and finishes and processing manufacturers.

Figure 3 A structured cluster

STRUCTURED CLUSTER (Interinstitutional Platform):

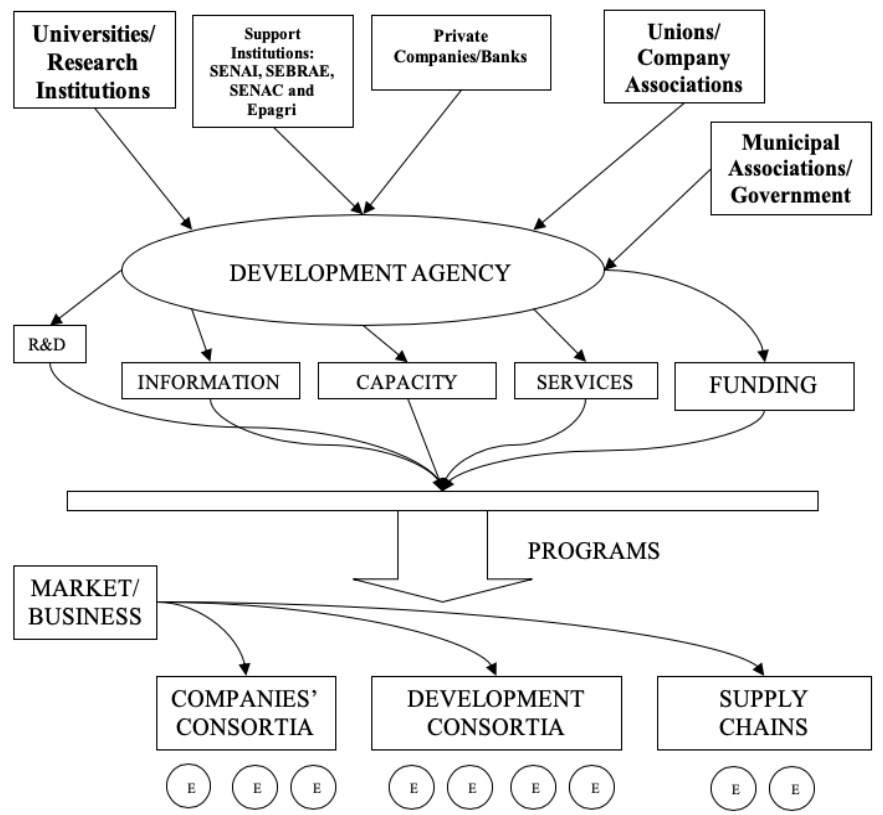

Source: Casarotto Filho and Pires (2000, p.137)

The Euvaldo Lodi Institute (IEL, 2003) in Santa Catarina produced in the year of 2001, six diagnoses for introducing production chains in Santa Catarina, with the support of FINEP. One of the diagnosis referred to the textile/clothing chain. Among retrieved information, major problems emerged and were identified and validated by companies' owners and support institutions of that production chain. The problems are grouped into factors of competitiveness:

Those concerning information: 
a lack of information and knowledge of the international market (clothing industry)

b lack of knowledge of available technologies to increase productivity (clothing industry)

c market, products and collections changes (clothing industry).

Those concerning technology:

a lack of competitiveness in international market (clothing industry)

b lack of knowledge of available technologies to increase productivity (clothing industry).

Those concerning integration:

a lack of an actor that provides a unity to companies (clothing industry)

b difficulties on finding partnerships for the products' diversification (clothing industry)

c lack of interaction among textiles and clothing associations (clothing industry)

d lack of partnership among cotton suppliers (clothing industry).

Those concerning training:

a lack of skilled workforce for last generation equipment (textile industry)

b lack of skilled workforce in textiles (textile industry).

Those concerning funding:

a lack of credit lines for renewal of manufacturing park and acquisition of manufacturing inputs (clothing industry)

b high rates for loans (textile industry).

Those concerning for other issues:

a transition of family-owned business to professional management (textile industry)

b companies operating in informality (clothing industry).

The underlined problems are directly linked to the absence of a structure that combine data, generate and disseminate information, and articulating regional actors around the interests of the supply chain. This structure can be provided with the establishment of an information/integration centre. Accordingly, the summary of the diagnosis concludes that:

It is missing an actor that provides unity to companies in the industry: despite having a forum for discussion about the chain, represented by the Fashion Chamber (involving the regional political leaders and the main actors of the private production chain), it suffers from an operational tool to implement the proposed and approved actions.

An instrument that could revitalise the Fashion Chamber could be a sectoral regional development agency - ADRS, as a mechanism for integrating the textile/clothing chain on Itajaí's Valley. This mechanism should be able to create collective programs for business development emphasising the promotion of 
information flows, with strong competitive content, focused on information technology, market, fashion trends, design and innovation, integrated to the support instruments available in the region (Soares, 1997). The main role of the ADRS will be the management of approved projects of the cluster and funding those projects via sectorial funds.

Among the characteristics, the sectorial ADR must have:

- to be able to permanently investigate the competitive and operational needs that associated companies and partnerships may show

- to facilitate the diffusion of these needs and combine them with available products and services in local institutional arrangement

- to establish a mechanism for the obtention and dissemination of technological, market and fashion trends information (competitive intelligence)

- to systematise and adapt information, transforming into an innovation and competitiveness sources for companies

- to promote technological cooperation and technology transfer

- to promote programs for collective development of companies pertaining to this regional production chain

- to promote institutional reputation in the production chain to potential customers

- to monitor the competitiveness of companies and local institutions (which directly impact on the competitiveness of companies and their products)

- to manage cluster's approved projects with resources from sectoral funds

- to establish the actors' relationship of the production chain with research institutions and universities for technological development

- to operationalise regional projects defined by the Fashion Chamber

- to integrate the projects of various local institutions dedicated to the chain in a multiinstitutional coordination (concept of interinstitutional platform)

- to integrate local public and private actors related to textile/clothing chain of the region.

To accomplish the aforementioned duties, it is needed:

- to know the companies' needs and organise a scheme for permanent upgrade

- to have a dynamic database of information about the chain

- to have a system of information obtention to share with companies and institutions

- to have a structure capable to assist products and services development with higher competitive content, capable to generate efficacy on the resources use of the technological support physical platform for companies.

The scheme of this centre follows the idea of the 'development lens', as shown in Figure 4. 
Figure 4 Model of an ADR sector for the textiles/clothing cluster of Itajaí's Valley-Santa Catarina, Brazil

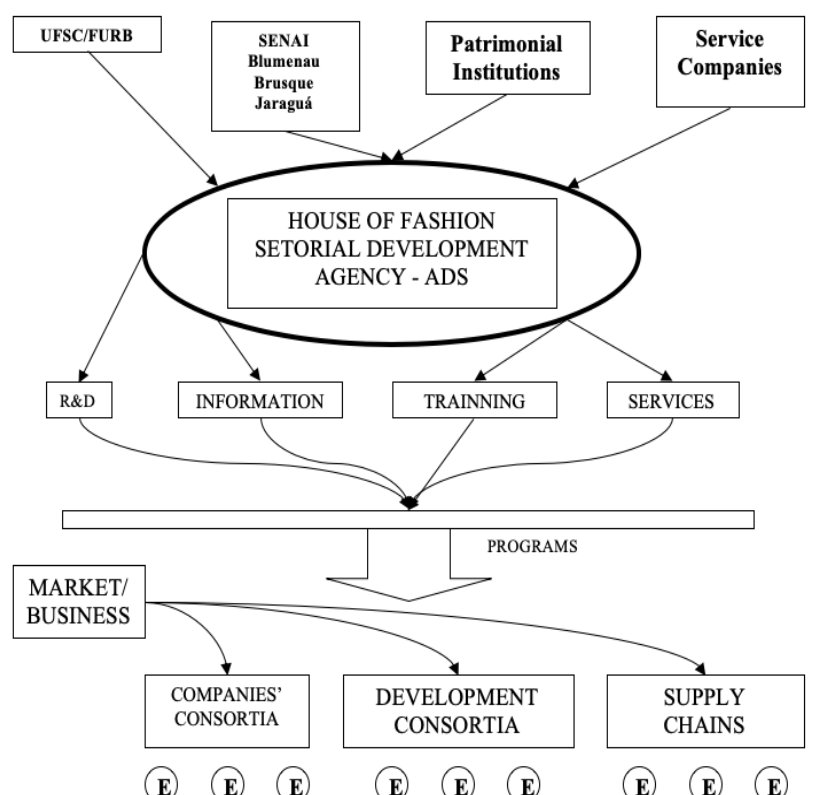

Source: Built based in Stamer et al. (1997)

The various support institutions in the region already have competencies in terms of $\mathrm{R} \& \mathrm{D}$, information, training and provision of technical services. The ADRS would be an instrument of assembly and management of various development projects for companies, especially supporting the value aggregation for various consortia or cooperation groups, some of them already under formation.

\section{Conclusions remarks}

It was presented a typical configuration of a productive local Italian system, especially focusing the region of Emilia Romagna, underlining the instruments for integration of third degree, i.e., those that act directly on a cluster development. The territory size for development was discussed. A vision that an integration instrument would works under a 'development lens' in an inter-institutional platform was presented.

It was noteworthy that, in Brazil, there are experiences on government levels at micro regional area, but those initiatives are still incipient. This is an obstacle for the implementation of similar models to those presented in Emilia Romagna. Although it was studied the case of textiles/clothing cluster of Itajaís Valley, a possible practical application of these concepts, by the creation of a sectorial ADR for the cluster, plays a key role for development. 
We suggest for future researches and, mainly, to practitioners that the intermediary levels of governance need to be addressed in order to favour a more organised and managed inter-institutional structure favouring clusters development. Although the governance theme is addressed in developed countries, there are challenges for their implementation in emerging countries, such the explored Brazilian case. We recommend to the governmental bodies of emerging countries to address the 'meso level' of governance to better target funding to industries that may be considered a priority in any government plan at regional level.

\section{References}

Becattini, G. (1979) 'Dal 'settore' industriale al 'distretto' industriale. Alcune considerazioni sull'unità d'indagine dell'economia industriale', Rivista di economia e politica industriale, Vol. 5, No. 1, pp.7-21.

Bertini, S. (2012) 'Regional governance and innovation in Emilia-Romagna', Apresentação, Seminário FAPESC/UFSC, Florianópolis, September.

Bianchi, P. (1995) Le Politiche Industriali dell'Unione Europea, II Mulino, Bologna.

Biancu, P.L. (2003) Desenvolvimento Turístico para o Estado da Bahia pela Comparação com o Sistema da Região da Sardenha, Master thesis (Master's in Production Engineering) Universidade Federal de Santa Catarina, Florianópolis.

Casarotto Filho, N. and Pires, L.H. (2000) Redes de Pequenas e Médias Empresas e Desenvolvimento Local, 2nd ed., Atlas, São Paulo.

Casarotto Filho, N. et al. (1996) 'A Experiência Italiana para o Desenvolvimento de Pequenas Indústrias em Santa Catarina', Fórum Catarinense de Desenvolvimento, Florianópolis.

Chamala, S. (1999) 'Overview of participative action approaches in Australian Land and Water management', in Chamala, S. and Keith, K. (Eds.): Participative Approaches for Landcare, AAP, Brisbane.

Coltorti, F. et al. (2016) 'Sintese del Rapporto', in Coltorti, F. et al. (Eds.): Rapporto 2015 - Il nuovo respire dei distretti tra ripresa e riposizionamento, Osservatorio Nazionale Distretti Italiani, Venezia.

Cossentino, F., Pyke, F. and Sengenberger, W. (1997) Le Risposte Locali e Regionali Alla Pressione Globale: il Caso Dell Ítalia e Dei Suoi Distretti Industrialli, Il Mulino, Bologna.

Esser, P. et al. (1994) Competitividad Sistémica: Competitividad Internacional de Las Empresas y Politicas Requeridas, IAD, Berlin.

European Union (2003) Regulation (EC) No 1059/2003 of the European Parliament and of The Council of 26 May 2003 on the establishment of a common classification of territorial units for statistics (NUTS) [online] https://eur-lex.europa.eu/legal-content/EN/TXT/PDF/?uri= CELEX:32003R $1059 \&$ from $=$ EN.

Euvaldo Lodi Institute (IEL) (2003) 'Gargalos da Cadeia Têxtil/Vestuário em Santa Catarina', in Coletânea de estudos sobre a competitividade de Arranjos e cadeias produtivas em Santa Catarina, BRDE, FIESC, FORUMCAT, Santa Catarina, Florianópolis.

Fumagalli, S. and Trenti, S. (2012) 'Il ruolo dell'innovazione tecnológica nel distretto dele macchine agricole di Modena e Reggio Emilia', in Mosconi, F. (Ed.): La metamorfose del modelo Emiliano: l'Emilia-Romagna e $i$ distretti industriali che cambiano, Il Molino, Bologna.

Gomes, G.M. (1997) Desenvolvimento e Política Regional na União Européia, IPEA, Rio de Janeiro.

Lorenzoni, G. (1992) Accordi, Reti e Vantaggio Competitivo, Etaslibri, Bologna.

Marshall, A. (1890) Principles of Economics, MacMillan, London. 
Mosconi, F. (2012) La metamorfose del modelo Emiliano: l'Emilia-Romagna e i distretti industriali che cambiano, Il Molino, Bologna.

Porter, M. (1999) Competição, Campus, Rio de Janeiro.

Saublens, C. et al. (1999) Clusters, Industrial Districts, Local Produtive Systems, Euro-rapport, No. 6, Eurada, Bruxelas.

Silveira, S.W. (1999) Da Abordagem Sistêmica para Diagnóstico da Vocação Competitiva e Desenvolvimento Microrregional - o caso de Blumenau, Master thesis (Master's in Production Engineering) Universidade Federal de Santa Catarina, Florianópolis.

Soares, V. (1997) Desenvolvimento Econômico Regional e Integração Interinstitucional, CDR, Setúbal.

Stamer, J.M. et al. (1997) Competitividade Sistêmica da Indústria Catarinense - relatório, IAD-FIESC, Florianópolis. 